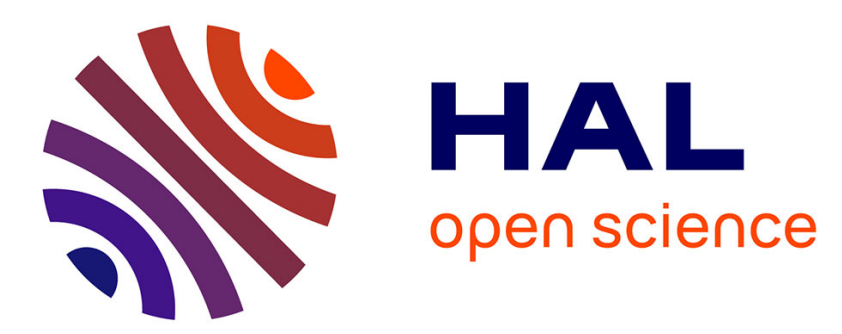

\title{
Optimization, continuation and lack of the one-step diphosphorylation reaction. Assay of modification of the tetraethyl(pyrrolidine-2,2-diyl)bisphosphonate
}

Gilles Olive, Alain Jacques

\section{- To cite this version:}

Gilles Olive, Alain Jacques. Optimization, continuation and lack of the one-step diphosphorylation reaction. Assay of modification of the tetraethyl(pyrrolidine-2,2-diyl)bisphosphonate. Phosphorus, Sulfur, and Silicon and the Related Elements, 2003, 178 (1), pp.33-46. hal-00660754

\section{HAL Id: hal-00660754 https://hal.science/hal-00660754}

Submitted on 17 Jan 2012

HAL is a multi-disciplinary open access archive for the deposit and dissemination of scientific research documents, whether they are published or not. The documents may come from teaching and research institutions in France or abroad, or from public or private research centers.
L'archive ouverte pluridisciplinaire $\mathbf{H A L}$, est destinée au dépôt et à la diffusion de documents scientifiques de niveau recherche, publiés ou non, émanant des établissements d'enseignement et de recherche français ou étrangers, des laboratoires publics ou privés. 


\section{Optimization, continuation and lack of the one-step diphosphorylation reaction. Assay of modification of the tetraethyl(pyrrolidine-2,2- diyl)bisphosphonate.}

Short Title: Diphosphorylation - New $\alpha$-aminobisphosphonates

\section{Gilles Olive $^{a^{*}}$ and Alain Jacques ${ }^{b}$}

Laboratoire OPEP, Rue Maison d'Orbais, 23/14, B-5032 CORROY-le-CHATEAU, Belgium ${ }^{a}$ and Laboratoire CSTR, Bâtiment Lavoisier, Place Louis Pasteur, 1, B-1348 Louvain-la-Neuve, Belgium ${ }^{b}$

The optimization of the one-step diphosphorylation reaction is reported. The synthesis of new $\alpha$-aminobisphosphonates with four and six-membered rings and acyclic species with several substituents on the nitrogen and on the carbon atom bearing the two phosphorus atoms is described.

Keywords: Amide; Bisphosphonates; Diphosphorylation; Lactam; Trialkylphosphite

\section{INTRODUCTION}

The gem-bisphosphonates show a structural analogy with pyrophosphoric acid. ${ }^{1}$ They are known for their various uses: dental (tooth pastes and mouthwashes) ${ }^{2-4}$ and medical applications (against rheumatoid arthritis,, 5 for the inhibition of bone resorptive processes such osteoporosis and Paget's disease, ${ }^{2,7-9}$ skeletal scintigraphy when combined with ${ }^{99} \mathrm{Tc},{ }^{10-}$ 12 breast cancer therapy, ${ }^{13}$ antiviral, ${ }^{14,15}$ anti-inflammatory ${ }^{16,17}$ and anti-rheumatismal agents, ${ }^{18}$ pain-easing activities, ${ }^{16}$ antimoebic ${ }^{15}$ ), antibacterial agents, ${ }^{19}$ plant growth regulators, ${ }^{20}$ herbicides, ${ }^{21-23}$ pesticides, ${ }^{19}$ in the nuclear industry, ${ }^{24-26}$ flame retardants ${ }^{21}$ and 
chelators in water treatment, ${ }^{21}$ etc... Gem-bisphosphonates and gem-bisphosphonic acids can readily form complexes with calcium and magnesium and this behavior is one of the principles sustaining their use as drugs. 3,15

Recently, amino-gem-bisphosphonates have been involved in the conformational study of pyrrolinoxyl radicals ${ }^{27}$ and they also work as spin trapping agents relevant to biology. ${ }^{28}$

Several procedures for the synthesis of $\alpha$-amino-bisphosphonates have already been reported in the literature. ${ }^{29,30}$ Unfortunately most of them are quite awkward to perform and require several steps. ${ }^{1,11,31-33}$ In 1994, Yokomatsu et al. were the first to describe an easy single step synthesis by a Beckmann rearrangement of oximes reagents (SCHEME 1 - Equation (1)). ${ }^{15}$ However we failed to extend this method to a five-membered ring bisphosphonate and found at least seven products by ${ }^{31} \mathrm{P}$ NMR in the crude reaction with only $10 \%$ of the target bisphosphonate. ${ }^{28}$ In 1997 and 1999, Qian et al. detailed a one pot but intricate two steps procedure involving Vilsmeier reagents and organophophorus compounds with $\mathrm{P}-\mathrm{H}$ bounds (SCHEME 1- Equation (2)). ${ }^{23,34}$ At the same time, we have designed an easy one step method also employing Vilsmeier reagents (amide or lactam/POCl 3 ) with trialkylphosphite. ${ }^{28,35}$

\section{INSERT SCHEME 1}

Schematically the experimental procedure is as follows: at low temperature, under nitrogen, $\mathrm{POCl}_{3}(0.22 \mathrm{~mol})$ was slowly added to a mixture of lactam or amide $(0.11 \mathrm{~mol})$ and trialkylphosphite $(0.21 \mathrm{~mol})$. The reaction mixture was then stirred at room temperature and then poured over a cold aqueous solution saturated with $\mathrm{NH}_{4} \mathrm{OH}$ (SCHEME 2).

\section{INSERT SCHEME 2}

* Address correspondence to Gilles Olive. E-mail: gilles.olive@excite.com. 
In the present paper, we will describe our optimization studies for the latter reaction parameters, new kinds of synthesis and also our failures. Because any change of the bisphosphonate properties is of interest for their use as a drug, we will also report our attempts toward modifying the tetraethyl(pyrrolidine-2,2-diyl)bisphosphonate.

\section{RESULTS AND DISCUSSION}

Optimization: all the optimizations were performed on the 2-pyrrolidinone.

Temperature: as elsewhere mentioned, 36 when the temperature raises above $40{ }^{\circ} \mathrm{C}$, the yield drops to about $5 \%$ due to the presence of gaseous $\mathrm{HCl}$; it is well known that hydrochloric acid can hydrolyze phosphonate (SCHEME 3).8,16,37 Similarly, when the initial temperature is too low for the reaction to occur or when the amide is frozen, the consequent removal of the cold source induces an exothermic reaction and possibly brings it to boil. In these circumstances, the yield is somewhat low and the presence of polymers can be encountered as it was the case with $N$-benzylacetamide. For the 2-pyrrolidinone, an optimum yield of $58 \%$ is obtained at $-7.5{ }^{\circ} \mathrm{C}$ and the adverse effect starts at $-10{ }^{\circ} \mathrm{C}$. It should be noted that a water bath at room temperature has to be used after the removal of the cold source in order to calm down the reaction.

\section{INSERT SCHEME 3}

Equivalent of $\mathrm{POCl}_{3}$ : according to Qian, ${ }^{23}$ only one equivalent of $\mathrm{POCl}_{3}$ has to be used but more satisfactory results can be obtained by incorporating two equivalents. ${ }^{28}$ Attempts 
with $1,1.5$ and 1.75 equivalents of $\mathrm{POCl}_{3}$ on 2-pyrrolidinone provide a yield of $56-57 \%$, close to what is obtained with two equivalents but the purity is lower as emphasized by the ${ }^{1} \mathrm{H}$, ${ }^{13} \mathrm{C}$ and ${ }^{31} \mathrm{P}$ spectra. Furthermore in these cases, we observed a change of colour and, after a few weeks, the presence of a small quantity of crystals.

Timing at room temperature: during our preliminary attempts, the crude mixture was hydrolyzed on ice and $\mathrm{NH}_{4} \mathrm{OH}$ just after the addition of $\mathrm{POCl}_{3}$. The corresponding product was pure and obtained with a good yield (58\%). It is actually advisable to wait for an hour at room temperature in order to allow the less reactive amide to react.

Continuation: all the products were purified by normal work-up for an amine (an acido-basic extraction) unless stated in the text.

Ring size: most of our efforts were focused on the five-membered rings. However we also investigated the synthesis from both 2-azitidinone and 2-piperidone (or $\delta$-valerolactam). Table I summarizes the results. 
TABLE I Influence of the ring size on the reaction

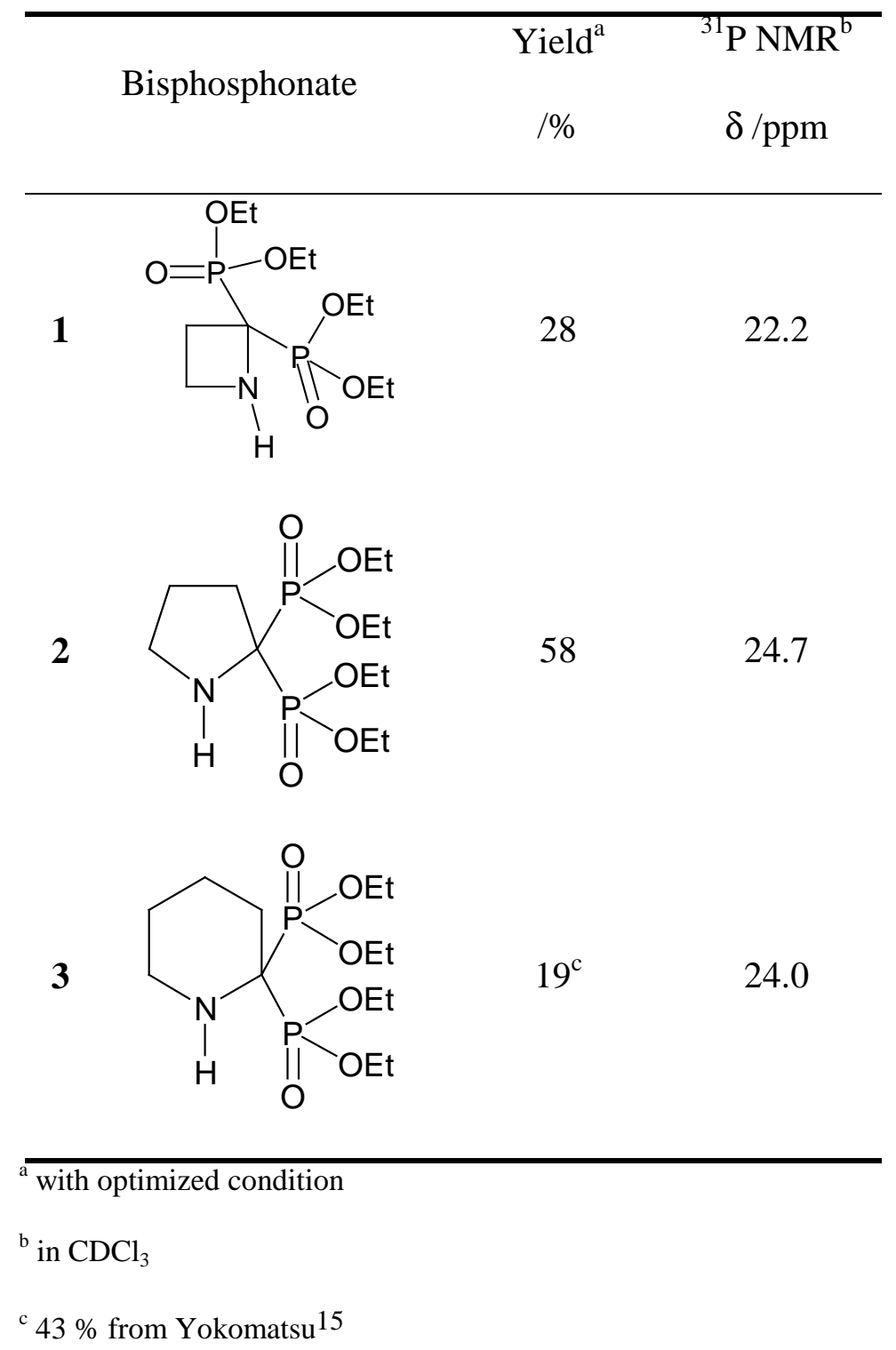

It has to be noticed that the synthesis of $\mathbf{3}$ by our procedure is less efficient than the one propounded by Yokomatsu (19\% yield versus $43 \%) .{ }^{15}$

Linear compounds: the results for the acyclic series are displayed on Table II; the yields have to be compared with those asserted in the literature. 
TABLE II Linear $\alpha$-aminobisphosphonate

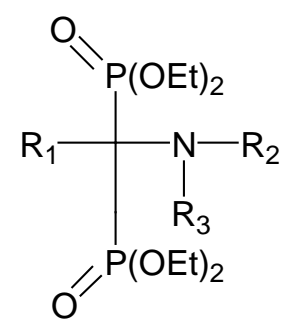

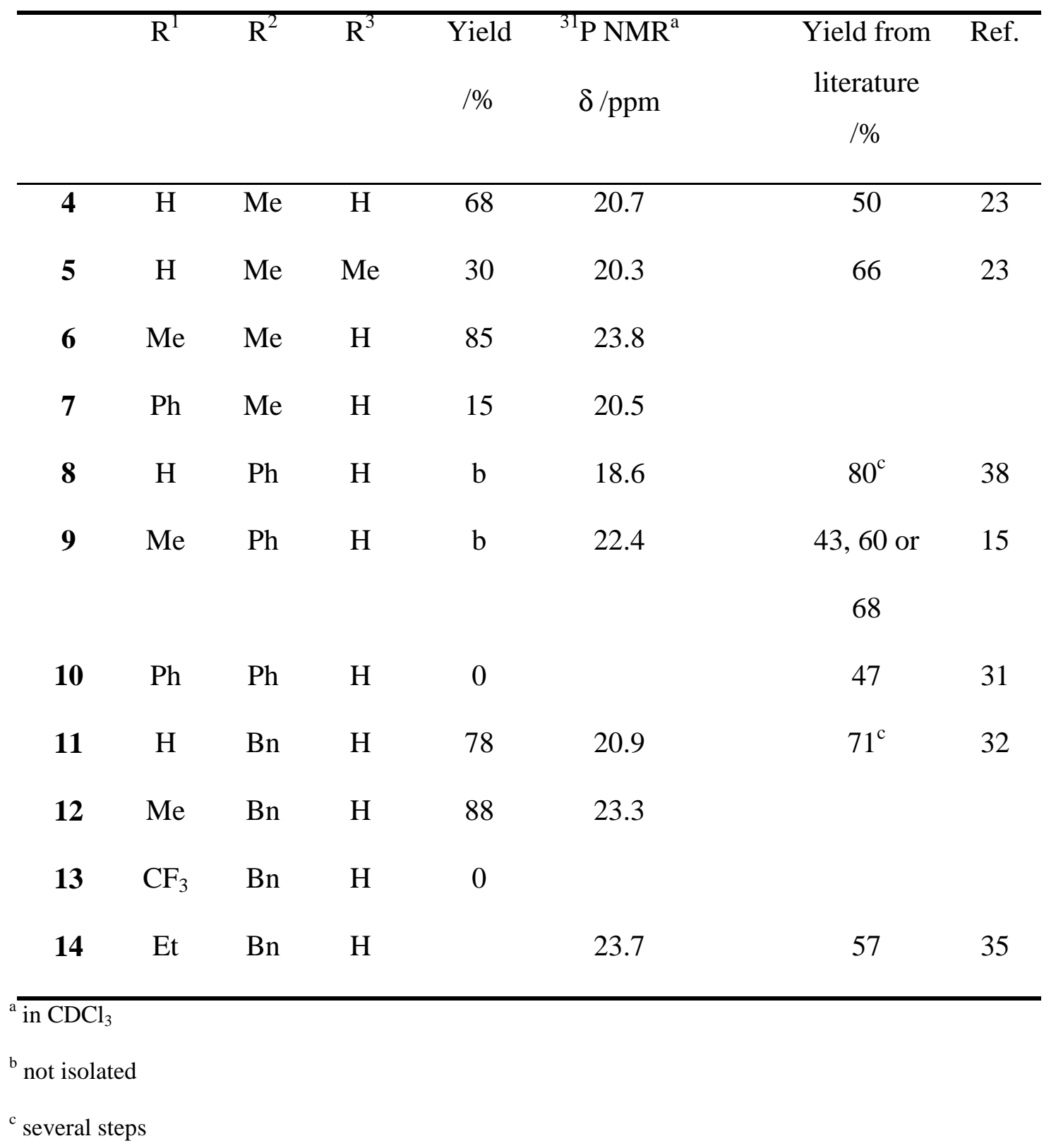

The yield of $\mathbf{4}$, the simplest bisphosphonate in the series, is higher than the one reported by Qian. ${ }^{23}$ If a second methyl group is added on the nitrogen (tertiary amine), the 
corresponding return is almost divided by a factor of two, being reduced from $68 \%$ to $30 \%$. This behavior has been previously described for the cyclic series by comparing the tetraethyl(pyrrolidine-2,2-diyl)bisphosphonate 2 and the tetraethyl( $N$-methyl-pyrrolidine-2,2diyl)bisphosphonate for which the yield drops from $47 \%$ to $17 \% .35$ Qian has obtained a better yield of $66 \%$ for compound 5. As emphasized by entries 6 and 12, a methyl group addition on the carbon atom bearing two phosphori significantly increases the yield, at least up to $80 \%$. If a phenyl group takes the place of the latter methyl, the corresponding yield is reduced to $15 \%$ (compound 7). In order to consolidate these observations, the $N$-benzyl series were synthesized (compounds 11, 12, 13 and 14). The best results were obtained with a methyl group, followed by a hydrogen atom and finally by an ethyl group. The synthesis of the trifluoromethyl compound failed, as mentioned in the lack section.

Considering the influence of the $N$-substitution, it appears that, in all the occurrences, the best yield is obtained with a benzyl group and to a lesser extent with a methyl group (compounds 4 and 11, 6 and 12). Unfortunately, the syntheses involving phenyl groups are hampered by inherent difficulties. The reactions occur but, in many cases, are incomplete: for compound $\mathbf{8}$ some of the triethylphosphite reactant remains and, for compound $\mathbf{9}$, some of the amide. Furthermore, these compounds cannot be satisfactorily purified due to the large number of spots found on the TLC.

As a general rule, it appears that the yields obtained by our procedure are higher than those reported in the literature with some exceptions regarding inefficient reactions as for tertiary amide and for $N$-phenyl compounds.

A NMR study of these linear bisphosphonates shows a dependable behaviour. The ${ }^{31} \mathrm{P}$ chemical shift are around $\delta 20.5 \mathrm{ppm}$ and $\delta 23.5 \mathrm{ppm}$, respectively for the formamide and acetamide. Similar observations are made on compound 10 in reference 35 and on compound 
7 from reference 39. The presence of a phenyl group on the nitrogen affects these ${ }^{31} \mathrm{P}$ chemical shifts with a respective increase of 2 and $1 \mathrm{ppm}$.

The ${ }^{13} \mathrm{C}$ NMR spectrum of compound 7 displays a distinctive upfield shift at $67 \mathrm{ppm}$ for the quaternary carbon bearing two phosphori when compared to the $57 \mathrm{ppm}$ shift measured on compounds 6 and 12. A small coupling of around $5 \mathrm{~Hz}$ between the quaternary phenyl carbon and the two phosphori can be measured on compounds $\mathbf{8}$ and $\mathbf{9}$. This is in agreement with the value reported by Yokomatsu. ${ }^{15}$

Synthesis of non symmetrical bisphosphonates: in the existing literature, 33,40 there have been very few reports devoted to non symmetrical bisphosphonates as depicted in SCHEME 4.

\section{INSERT SCHEME 4}

By applying our procedure to 2-pyrrolidinone in the presence of one equivalent of $\mathrm{P}(\mathrm{OEt})_{3}$ and one equivalent of $\mathrm{P}(\mathrm{OiPr})_{3}$, a mixture of three products $\mathbf{2}, \mathbf{1 5}$ and $\mathbf{1 6}$ is obtained (SCHEME 5). Unexpectedly, $25 \%-25 \%-50 \%$ proportions have been measured by ${ }^{31} \mathrm{P}$ NMR and HPLC analysis instead of the expected $33 \%-33 \%-33 \%$ ratios. Considering that the distillation treatment failed, a pure sample of compound $\mathbf{1 6}$ was only achieved by a preparative HPLC.

\section{INSERT SCHEME 5}

In a previous publication, ${ }^{28}$ the study of the ${ }^{13} \mathrm{C}$ NMR spectrum of the methyl on the phosphono group led to the conclusion that the ${ }^{2} J_{\mathrm{pp}}$ coupling constant had to be larger than 15 
Hz. In the view of the newly synthesized bisphosphonates, this coupling constant has been resolved to $58 \mathrm{~Hz}$. It has to be noticed that all NMR spectra obtained from these compounds are the sum of the data corresponding to $\mathbf{2}$ and $\mathbf{1 5}$ with the exception of the ${ }^{31} \mathrm{P}$ spectra.

Lacks: All the cases of deficiencies that we encountered fall into three categories that are summarized on Table III: the reactants failed to react, the reaction went wrong, the products were unstable or could not be purified. 
TABLE III Lack

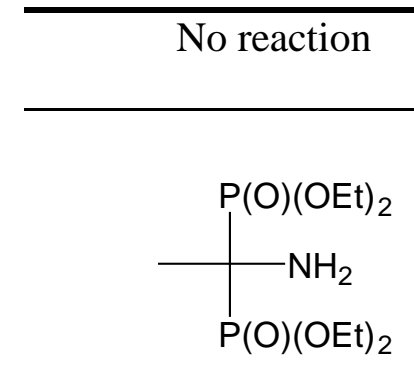

17<smiles>CCOCC(N)(Cc1ccccc1)P(OCC)OCC</smiles>

18

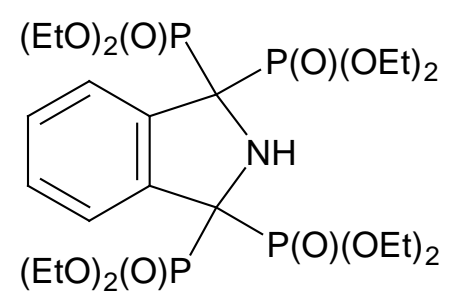

19<smiles>CCOC(=O)C(Nc1ccccc1)(c1ccccc1)C(OCC)OCC</smiles>

10<smiles>CCOC(=O)C(NCc1ccccc1)(PCC)C(F)(F)F</smiles>

13
Wrong Reaction

Unstable

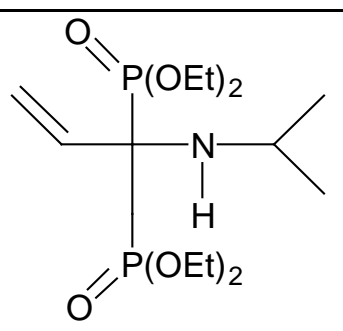

20

21<smiles>CCOC(=O)[C@H]1CCC(P(=O)(OCC)OCC)(P(=O)(OCC)OCC)N1</smiles>

22<smiles>CCOC(=O)C(Nc1ccccc1)C(OCC)OCC</smiles>

8<smiles>CCOC(=O)C(C)(Nc1ccccc1)[PH2]CC</smiles> 
Surprisingly, primary amides as in $\mathbf{1 7}$ and $\mathbf{1 8}$ are not keen to react and only the corresponding hydrolysis product of the triethylphosphite has been found. Compound $\mathbf{1 9}$ only duplicates a lack that has been already described for succinimide ${ }^{35}$ and confirms that tetraphosphonates cannot be obtained in this way. The failure of compound $\mathbf{1 0}$ probably comes from steric hindrance. Nevertheless the latter can be attained by the Kreutzkamp synthesis. ${ }^{31}$ It is likely that the high electronegativity of the fluorine prevents the $N$ benzyltrifluoroactamide from reacting (compound 13).

Fortunately, compound $\mathbf{2 0}$ is the only case where the reaction goes wrong. However a

${ }^{31} \mathrm{P}$ NMR study on its products allows to rule out a potential polymerization.

All the compounds reported in the third column of Table III have been identified by their respective NMR spectra.

$\alpha$-amino methoxyphosphonates are known to undergo aminolysis reactions (SCHEME 6). ${ }^{41,42}$ This probably happens while synthesizing compound $\mathbf{2 1}$ which appears to be awkward to purify due to its instability. However, its NMR spectrum has been quickly acquired after several preparative TLC. The presence of an ester group apparently hinders a proper build-up of compound 22. Its formation can be assumed by the appearance of two peaks in the ${ }^{31} \mathrm{P}$ NMR spectrum and of a characteristic quaternary carbon triplet at $62.3 \mathrm{ppm}$ with a coupling constant of $129 \mathrm{~Hz}$ in the ${ }^{13} \mathrm{C}$ NMR spectrum. Unfortunately, these spectra also reveal several by-products as validated by a TLC (11 spots). As earlier discussed, compounds 8 and $\mathbf{9}$ could not be purified; their TLC carry 16 and 12 spots respectively.

\section{INSERT SCHEME 6}

Assay of modification of the tetraethyl(pyrrolidine-2,2-diyl)bisphosphonate: two different sites of the $\alpha$-aminophosphonates can potentially be modified: the phosphorus atoms and the 
nitrogen atom. However, most of our attempts led to failures. In order to enhance the biodisponibility of the phosphonates, these alterations are usually required. It seems that the most problematic task is to enhance their lipophilicity by lowering the polarity while maintaining their complexing behaviour. ${ }^{26}$

Modifications on the phosphorus atoms: our first efforts were devoted to synthesize compound 23 (SCHEME 7) by applying the second procedure described by Vepsäläinen. ${ }^{43}$ Therefore compound 2 from Table I has been heated at $110{ }^{\circ} \mathrm{C}$ with ten equivalents of piperidine for twenty minutes. The resulting mixture still contains some of the starting reactants but its ${ }^{31} \mathrm{P}$ NMR study reveals the presence of two coupled phosphorus atoms at 29 ppm and 18 ppm shifts with a $43 \mathrm{~Hz}$ coupling constant which is incompatible with the structure of equivalent phosphori.

\section{INSERT SCHEME 7}

The aim of our second attempt was to synthesize compound 24. Nothing arose from adding twenty equivalents of pyridine to molecule $\mathbf{2}$ and warming the mixture to $120{ }^{\circ} \mathrm{C}$ for fifteen minutes. If it is left to stand for one night, a complete degradation of compound 2 occurs.

Our conclusion is the same as Herlinger's ${ }^{26}$ introduction: the preparation of a partial ester is difficult due to the poor selectivity of the involved reactions.

Modifications on the nitrogen atom: at first, the synthesis of the quaternary ammonium molecule 25 has been attempted (SCHEME 8). The objective was to open the five-membered ring by an Hofmann elimination. The resulting molecule would have provided a convenient 
building block for different kinds of pathways (SCHEME 9). Unfortunately, no reaction takes place when molecule $\mathbf{2}$ is mixed with iodomethane in diethyl ether. However a complex mixture is obtained after $72 \mathrm{~h}$ in pure $\mathrm{CH}_{3} \mathrm{I}$; the corresponding ${ }^{31} \mathrm{P}$ NMR spectrum shows 21 peaks and some of the starting reactant remains. This result is compatible with reference 44 .

\section{INSERT SCHEME 8}

\section{INSERT SCHEME 9}

Our second attempt was to build compound $\mathbf{2 6}$ and, from it, a tetraphosphorus molecule, whose direct synthesis appears not feasible. The reaction yields an inseparable mixture of three components (the expected end product, the related ammonium form and the starting acylchloride). Unfortunately, it degrades after a few days.

The synthesis of compound $\mathbf{2 7}$ is our only successful alteration on the nitrogen. It is readily obtained by dissolving $\mathbf{2}$ in hydrochloric acid and by freely evaporating the remaining water. Its NMR study provides a valuable insight into the reaction mechanism. Furthermore, it shows a similar behaviour as described by Pietri et al. in Krebs conditions: the conversion from the acidic to the basic form comes with an NMR shift from 24 to $17 \mathrm{ppm} .{ }^{45}$

\section{CONCLUSION}

By optimizing the temperature during the addition of $\mathrm{POCl}_{3}$, the quantity of $\mathrm{POCl}_{3}$ equivalents and the amount of time at room temperature, we have significantly increased the yields as for example from 48 to $58 \%$ in the case of $\mathbf{2}$. The synthesis of new cyclic or acyclic compounds and the modifications brought to some of the aminobisphosphonates give a 
valuable insight into the reaction process. These are still under investigation in our laboratory. Apart from the tertiary amides and from the $N$-phenyl compounds, it appears that the yields obtained by our procedure for linear compounds are higher than those reported in the literature. Furthermore we hope that the description of our failures provides some interesting information.

\section{Experimental section}

Synthesis and Characterizations. General. NMR spectra were performed on a Varian Inova $400\left({ }^{1} \mathrm{H}, 400.16 \mathrm{MHz},{ }^{13} \mathrm{C}, 100.63 \mathrm{MHz},{ }^{31} \mathrm{P}, 162.00 \mathrm{MHz}\right)$ or on a Varian Gemini $300\left({ }^{1} \mathrm{H}\right.$, 300.046 MHz, $\left.{ }^{13} \mathrm{C}, 75.454 \mathrm{MHz},{ }^{31} \mathrm{P}, 121.460 \mathrm{MHz}\right)$ spectrometer. $\delta$ are given in ppm and referred to internal TMS for ${ }^{1} \mathrm{H}$ and ${ }^{13} \mathrm{C}$ and to external $85 \% \mathrm{H}_{3} \mathrm{PO}_{4}$ for ${ }^{31} \mathrm{P} .{ }^{15} \mathrm{~N}-\mathrm{NMR}$ spectra were recorded on a Varian Inova 500 at $50.649 \mathrm{MHz}$ (Inverse gated method) and the chemical shifts $(\delta)$ in ppm referred to external $\mathrm{CD}_{3} \mathrm{NO}_{2}$. All $J$ values are given in $\mathrm{Hz}$. Elemental analyses were determined in the Eindhoven University of Technology. Solvents were purchased from Biosolve. All starting materials were Aldrich reagents and were used as purchased, unless otherwise indicated.

General optimized procedure. In a double walled flask, under nitrogen, phosphorus oxichloride $(20 \mathrm{ml}, 0.22 \mathrm{~mol})$ was added in $1 \mathrm{~h}$ time to a mixture at $-7.5^{\circ} \mathrm{C}$ of amide or lactam $(0.11 \mathrm{~mol})$ and trialkylphosphite $(0.21 \mathrm{~mol})$. The reaction mixture was stirred for 1 hour at room temperature and then poured over a mixture of ice (200 g) and ammonia $30 \%$ (400 ml). The aqueous layer was extracted with methylene chloride $(3 \times 100 \mathrm{ml})$ and then the latter was removed to obtain an oil. The oil was dissolved in $100 \mathrm{ml}$ of methylene chloride. An aqueous solution of hydrochloric acid (10 $\mathrm{ml}$ of $32 \% \mathrm{HCl}$ solution, $190 \mathrm{ml}$ of water) was added (check 
that $\mathrm{pH}$ 1) and the aqueous layer was washed with methylene chloride (3 x $100 \mathrm{ml})$. A solution of sodium hydroxide (200 g. $\left.\mathrm{l}^{-1}\right)$ was added up to $\mathrm{pH} 10$ and the aqueous layer was extracted with methylene chloride $(4 \mathrm{x} 100 \mathrm{ml})$. The organic layer was dried over sodium sulfate, filtered and the removal of the solvent afforded the desired bisphosphonates.

Tetraethyl(azetidine-2,2-diyl)bisphosphonate 1 (slightly yellow liquid, 10.14 g, $28 \%$ ).

${ }^{1} \mathrm{H}-\mathrm{NMR}\left(400 \mathrm{MHz}, \mathrm{CDCl}_{3}\right) \delta 1.17\left(12 \mathrm{H}, \mathrm{t}, J=7.2,4 \mathrm{CH}_{3} \mathrm{CH}_{2} \mathrm{O}\right), 2.23(1 \mathrm{H}, \mathrm{s}, \mathrm{NH}), 2.64(2 \mathrm{H}$, tt, $\left.J_{\mathrm{PH}}=17.4, J_{\mathrm{HH}}=8.0, \mathrm{CH}_{2} \mathrm{CP}_{2}\right), 3.54\left(2 \mathrm{H}, \mathrm{t}, J=7.8, \mathrm{CH}_{2} \mathrm{~N}\right), 4.06\left(8 \mathrm{H}, \mathrm{m}, 4 \mathrm{CH}_{3} \mathrm{CH}_{2} \mathrm{O}\right) .{ }^{13} \mathrm{C}-$ NMR (100 MHz, $\left.\mathrm{CDCl}_{3}\right) \delta 16.1\left(2 \mathrm{t}, J=3.1,4 \mathrm{CH}_{3} \mathrm{CH}_{2} \mathrm{O}\right), 25.2\left(\mathrm{t}, J=6.1, C \mathrm{H}_{2} \mathrm{CP}_{2}\right), 45.3(\mathrm{t}$, $\left.J=7.2, C \mathrm{H}_{2} \mathrm{~N}\right), 60.3\left(\mathrm{t}, J=149.2, C \mathrm{P}_{2}\right), 62.6\left(\mathrm{t}, J=3.0,2 \mathrm{CH}_{3} C \mathrm{H}_{2} \mathrm{O}\right), 63.1(\mathrm{t}, J=3.5,2$ $\left.\mathrm{CH}_{3} \mathrm{CH}_{2} \mathrm{O}\right) .{ }^{31} \mathrm{P}-\mathrm{NMR}\left(162 \mathrm{MHz}, \mathrm{CDCl}_{3}\right) \delta$ 22.2. Anal. Calcd for $\mathrm{C}_{11} \mathrm{H}_{25} \mathrm{NO}_{6} \mathrm{P}_{2}: \mathrm{C}, 40.13 ; \mathrm{H}$, 7.65; N, 4.25. Found: C, 40.21; H, 7.55; N, 4.12.

Tetraethyl(N-methyl-1-aminoethan-1,1-diyl)bisphosphonate 6 (slightly yellow liquid, $29.20 \mathrm{~g}$, $84 \%)$

${ }^{1} \mathrm{H}-\mathrm{NMR}\left(300 \mathrm{MHz}, \mathrm{CDCl}_{3}\right) \delta 1.36\left(12 \mathrm{H}, \mathrm{t}, J=6.9,4 \mathrm{CH}_{3} \mathrm{CH}_{2} \mathrm{O}\right), 1.56\left(3 \mathrm{H}, \mathrm{t}, J_{\mathrm{PH}}=17.0\right.$, $\left.\mathrm{CH}_{3} \mathrm{CP}_{2}\right), 1.77(1 \mathrm{H}, \mathrm{ls}, \mathrm{NH}), 2.55\left(3 \mathrm{H}, \mathrm{s}, \mathrm{CH}_{3} \mathrm{~N}\right), 4.23\left(8 \mathrm{H}, \mathrm{m}, 4 \mathrm{CH}_{3} \mathrm{CH}_{2} \mathrm{O}\right) .{ }^{13} \mathrm{C}-\mathrm{NMR}(75$ $\left.\mathrm{MHz}, \mathrm{CDCl}_{3}\right) \delta 14.8\left(\mathrm{t}, J=3.8, C_{3} \mathrm{CP}_{2}\right), 15.8\left(\mathrm{t}, J=2.7,4 \mathrm{CH}_{3} \mathrm{CH}_{2} \mathrm{O}\right), 29.5\left(\mathrm{t}, J=6.5, C \mathrm{H}_{3} \mathrm{~N}\right)$, 56.8 (t, $J=143.8, C \mathrm{P}_{2}$ ), 62.0 (t, $J=3.8,2 \mathrm{CH}_{3} \mathrm{CH}_{2} \mathrm{O}$ ), 62.3 (t, J=3.2, $2 \mathrm{CH}_{3} C \mathrm{H}_{2} \mathrm{O}$ ). ${ }^{31} \mathrm{P}-\mathrm{NMR}$ $\left(121 \mathrm{MHz}, \mathrm{CDCl}_{3}\right) \delta$ 23.8. Anal. Calcd for $\mathrm{C}_{11} \mathrm{H}_{27} \mathrm{NO}_{6} \mathrm{P}_{2}$ : C, 39.88; H, 8.21; N, 4.23. Found: C, 40.02; H, 8.30; N, 4.20. $\mathrm{R}_{\mathrm{f}}\left(\mathrm{EtOH} / \mathrm{CH}_{2} \mathrm{Cl}_{2}\right.$ 0.5/9.5) $=0.52$.

Tetraethyl(N-methyl-1-amino-1-phenylmethane-1,1-diyl)bisphosphonate 7 (colorless liquid, $6.00 \mathrm{~g}, 15 \%)$. 
${ }^{1} \mathrm{H}-\mathrm{NMR}\left(300 \mathrm{MHz}, \mathrm{CDCl}_{3}\right) \delta 1.20\left(6 \mathrm{H}, \mathrm{t}, J=6.9,2 \mathrm{CH}_{3} \mathrm{CH}_{2} \mathrm{O}\right), 1.29(6 \mathrm{H}, \mathrm{t}, J=7.1,2$ $\left.\mathrm{CH}_{3} \mathrm{CH}_{2} \mathrm{O}\right), 2.48\left(3 \mathrm{H}, \mathrm{s}, \mathrm{CH}_{3} \mathrm{~N}\right), 4.11\left(8 \mathrm{H}, \mathrm{m}, 4 \mathrm{CH}_{3} \mathrm{CH}_{2} \mathrm{O}\right), 7.35$ (3H, m, Aromatics ortho and para), $7.82\left(2 \mathrm{H}, \mathrm{m}\right.$, Aromatics meta). ${ }^{13} \mathrm{C}-\mathrm{NMR}\left(75 \mathrm{MHz}, \mathrm{CDCl}_{3}\right) \delta 15.8(\mathrm{t}, J=3.2,2$ $\left.C \mathrm{H}_{3} \mathrm{CH}_{2} \mathrm{O}\right), 15.9$ (t, J=3.2, $\left.2 \mathrm{CH}_{3} \mathrm{CH}_{2} \mathrm{O}\right), 30.6\left(\mathrm{t}, J=9.1, C \mathrm{H}_{3} \mathrm{~N}\right), 62.9\left(\mathrm{t}, J=3.8,2 \mathrm{CH}_{3} \mathrm{CH}_{2} \mathrm{O}\right)$, 63.0 (t, $J=3.2,2 \mathrm{CH}_{3} \mathrm{CH}_{2} \mathrm{O}$ ), 67.4 (t, $J=136.8, C \mathrm{P}_{2}$ ), 126.8 (t not resolved, Aromatics para), 127.0 (t not resolved, Aromatics meta), 128.4 (t, $J=5.4$, Aromatics ortho), 131.8 (t, $J=3.8$, quaternary aromatic). ${ }^{31} \mathrm{P}-\mathrm{NMR}\left(121 \mathrm{MHz}, \mathrm{CDCl}_{3}\right) \delta$ 20.5. Anal. Calcd for $\mathrm{C}_{16} \mathrm{H}_{29} \mathrm{NO}_{6} \mathrm{P}_{2}$ : C, 48.86; H, 7.43; N, 3.56. Found: C, 49.32; H, 7.03; N, 3.76. $\mathrm{R}_{\mathrm{f}}\left(\mathrm{EtOH} / \mathrm{CH}_{2} \mathrm{Cl}_{2}\right.$ 0.5/9.5)=0.60.

Tetraethyl(N-benzyl-1-aminoethan-1,1-diyl)bisphosphonate 12 (orange liquid, 33.48 g, 88 \%). ${ }^{1} \mathrm{H}-\mathrm{NMR}\left(300 \mathrm{MHz}, \mathrm{CDCl}_{3}\right) \delta 1.38\left(12 \mathrm{H}, \mathrm{m}, 4 \mathrm{CH}_{3} \mathrm{CH}_{2} \mathrm{O}\right), 1.67\left(3 \mathrm{H}, \mathrm{t}, J_{\mathrm{PH}}=16.8, \mathrm{CH}_{3} \mathrm{CP}_{2}\right)$, $4.06\left(2 \mathrm{H}, \mathrm{s}, \mathrm{CH}_{2} \mathrm{~N}\right), 4.38\left(8 \mathrm{H}, \mathrm{m}, 4 \mathrm{CH}_{3} \mathrm{CH}_{2} \mathrm{O}\right), 7.36\left(5 \mathrm{H}, \mathrm{m}\right.$, Aromatics). ${ }^{13} \mathrm{C}-\mathrm{NMR}(75 \mathrm{MHz}$, $\left.\mathrm{CDCl}_{3}\right) \delta 16.1\left(\mathrm{t}, J=3.2,4 \mathrm{CH}_{3} \mathrm{CH}_{2} \mathrm{O}\right.$ and $\left.\mathrm{CH}_{3} \mathrm{CP}_{2}\right), 47.4\left(\mathrm{t}, J=5.9, C \mathrm{H}_{2} \mathrm{~N}\right), 57.4(\mathrm{t}, J=142.7$, $C \mathrm{P}_{2}$ ), 62.4 (t, $J=3.8,2 \mathrm{CH}_{3} \mathrm{CH}_{2} \mathrm{O}$ ), 62.9 (t, $J=3.2,2 \mathrm{CH}_{3} \mathrm{CH}_{2} \mathrm{O}$ ), 126.3 (Aromatic para), 127.6 and 127.7 (Aromatics ortho and meta), 139.8 (quaternary aromatic). ${ }^{31} \mathrm{P}-\mathrm{NMR}$ (121 MHz, $\left.\mathrm{CDCl}_{3}\right) \delta$ 23.3. Anal. Calcd for $\mathrm{C}_{17} \mathrm{H}_{31} \mathrm{NO}_{6} \mathrm{P}_{2}: \mathrm{C}, 50.12 ; \mathrm{H}, 7.67 ; \mathrm{N}, 3.44$. Found: $\mathrm{C}, 49.88 ; \mathrm{H}$, $7.41 ; \mathrm{N}, 3.04$.

P,P-Diethyl-P',P'-diisopropyl(pyrrolidine-2,2-diyl)bisphosphonate 16 (colorless liquid, $9.85 \mathrm{~g}$, $25 \%)$.

16 was purified by preparative HPLC on a Kromasil column $(10 \mu \mathrm{m}, \Phi$ int $=50 \mathrm{~mm}, \mathrm{~L}=25 \mathrm{~cm})$ with $\mathrm{CH}_{3} \mathrm{CN} / \mathrm{H}_{2} \mathrm{O}$ 60/40 as eluent. Rate: $50 \mathrm{ml} \cdot \mathrm{mn}^{-1} .70 \mathrm{mg}$ by injection. UV detector at 204 nm. $\mathrm{T}_{\mathrm{R}}$ (Kromasil column $10 \mu \mathrm{m}, \mathrm{CH}_{3} \mathrm{CN} / \mathrm{H}_{2} \mathrm{O}$ 60/40, rate: $0.5 \mathrm{ml} . \mathrm{mn}^{-1}$, UV detector at 204 $\mathrm{nm})=7.57 \mathrm{mn}$. 
${ }^{1} \mathrm{H}-\mathrm{NMR}\left(300 \mathrm{MHz}, \mathrm{CDCl}_{3}\right) \delta 1.35\left(6 \mathrm{H}, \mathrm{t}, J=7.8,2 \mathrm{CH}_{3} \mathrm{CH}_{2} \mathrm{O}\right), 1.37(12 \mathrm{H}, \mathrm{d}, J=6.6,2$ $\left.\left(\mathrm{CH}_{3}\right)_{2} \mathrm{CHO}\right), 1.88\left(2 \mathrm{H}, \mathrm{t}, J=6.7, \mathrm{CH}_{2} \mathrm{CH}_{2} \mathrm{CH}_{2}\right), 2.30\left(2 \mathrm{H}, \mathrm{m}, \mathrm{CH}_{2} \mathrm{CP}_{2}\right), 3.07(2 \mathrm{H}, \mathrm{t}, J=6.5$, $\left.\mathrm{CH}_{2} \mathrm{~N}\right), 4.21\left(4 \mathrm{H}, \mathrm{m}, 2 \mathrm{CH}_{3} \mathrm{CH}_{2} \mathrm{O}\right), 4.82\left(2 \mathrm{H}, \mathrm{m}, 2\left(\mathrm{CH}_{3}\right)_{2} \mathrm{CHO}\right) .{ }^{13} \mathrm{C}-\mathrm{NMR}\left(75 \mathrm{MHz}, \mathrm{CDCl}_{3}\right)$ $\delta 16.2\left(\mathrm{t}, J=4.9,2 \mathrm{CH}_{3} \mathrm{CH}_{2} \mathrm{O}\right), 23.5\left(\mathrm{t}, J=5.4,2\left(\mathrm{CH}_{3}\right)_{2} \mathrm{CHO}\right), 24.0\left(\mathrm{~d}, J=3.2,\left(\mathrm{CH}_{3}\right)_{2} \mathrm{CHO}\right)$, $24.1\left(\mathrm{~d}, J=3.2,\left(\mathrm{CH}_{3}\right)_{2} \mathrm{CHO}\right), 25.8\left(\mathrm{t}, J=3.2, \mathrm{CH}_{2} \mathrm{CH}_{2} \mathrm{CH}_{2}\right), 30.2\left(\mathrm{t}, J=2.7, C \mathrm{H}_{2} \mathrm{P}_{2}\right), 47.1$ (t) $\left.J=4.3, C \mathrm{H}_{2} \mathrm{~N}\right), 61.5\left(\mathrm{t}, J=152.9, C \mathrm{P}_{2}\right), 62.4\left(\mathrm{~d}, J=7.5, \mathrm{CH}_{3} \mathrm{CH}_{2} \mathrm{O}\right), 62.9\left(\mathrm{~d}, J=7.5, \mathrm{CH}_{3} \mathrm{CH}_{2} \mathrm{O}\right)$, $71.0\left(\mathrm{~d}, J=7.5,\left(\mathrm{CH}_{3}\right)_{2} \mathrm{CHO}\right), 71.6$ (d, J=7.5, $\left.\left(\mathrm{CH}_{3}\right)_{2} \mathrm{CHO}\right) .{ }^{31} \mathrm{P}-\mathrm{NMR}\left(162 \mathrm{MHz}, \mathrm{CDCl}_{3}\right)$ $\delta 22.7\left(\mathrm{~d}, J_{\mathrm{PP}}=59, P(\mathrm{O} i \mathrm{Pr})_{2}, 24.9\left(\mathrm{~d}, J_{\mathrm{PP}}=58, P(\mathrm{OEt})_{2} \cdot{ }^{15} \mathrm{~N}-\mathrm{NMR}\left(\mathrm{C}_{6} \mathrm{D}_{6}\right) \delta-340.4\left(\mathrm{t}, J_{\mathrm{N}-\mathrm{P}}=\right.\right.\right.$ 9.3). Anal. Calcd for $\mathrm{C}_{14} \mathrm{H}_{31} \mathrm{NO}_{6} \mathrm{P}_{2}$ : C, 45.28; H, 8.41; N, 3.77. Found: $\mathrm{C}, 45.21 ; \mathrm{H}, 8.55 ; \mathrm{N}$, 4.02 .

Tetraethyl(pyrrolidine-2,2-diyl)bisphosphonate hydrochloride 27 (1.08 g, 98 \%).

In a $10 \mathrm{ml}$ flask, tetraethyl(pyrrolidine-2,2-diyl)bisphosphonate $2(1.00 \mathrm{~g}, 2.9 \mathrm{mmol})$ and an hydrochloric acid solution $\left(10 \mathrm{ml} \mathrm{HCl} 32 \%\right.$ and $\left.90 \mathrm{ml} \mathrm{H}_{2} \mathrm{O}\right)$ was kept at room temperature for 3 days and then the water was removed under reduced pressure to give $1.08 \mathrm{~g}$ (yield $=98 \%$ ) of dark yellow oil.

${ }^{1} \mathrm{H}-\mathrm{NMR}\left(400 \mathrm{MHz}, \mathrm{CDCl}_{3}\right) \delta 1.30\left(12 \mathrm{H}, \mathrm{t}, J=7.2,4 \mathrm{CH}_{3} \mathrm{CH}_{2} \mathrm{O}\right), 2.11$ (2H, quint., $J=7.0$, $\left.\mathrm{CH}_{2} \mathrm{CH}_{2} \mathrm{CH}_{2}\right), 2.49\left(2 \mathrm{H}, \mathrm{m}, \mathrm{CH}_{2} \mathrm{CP}_{2}\right), 3.55\left(2 \mathrm{H}, \mathrm{t}, \mathrm{J}=7.0, \mathrm{CH}_{2} \mathrm{~N}\right), 4.22\left(8 \mathrm{H}, \mathrm{m}, 4 \mathrm{CH}_{3} \mathrm{CH}_{2} \mathrm{O}\right)$, $8.30\left(2 \mathrm{H}, \mathrm{s}, 2 \mathrm{NH} \mathrm{H}_{2}\right){ }^{13} \mathrm{C}-\mathrm{NMR}\left(100 \mathrm{MHz}, \mathrm{CDCl}_{3}\right) \delta 15.9\left(4 \mathrm{CH}_{3} \mathrm{CH}_{2} \mathrm{O}\right), 24.1\left(\mathrm{CH}_{2} \mathrm{CH}_{2} \mathrm{CH}_{2}\right)$, $31.0\left(\mathrm{CH}_{2} \mathrm{P}_{2}\right), 49.0\left(\mathrm{CH}_{2} \mathrm{~N}\right), 62.9\left(\mathrm{t}, J=146.0, C \mathrm{P}_{2}\right), 65.3\left(4 \mathrm{CH}_{3} \mathrm{CH}_{2} \mathrm{O}\right) .{ }^{31} \mathrm{P}-\mathrm{NMR}(162 \mathrm{MHz}$, $\left.\mathrm{CDCl}_{3}\right) \delta$ 16.9. Anal. Calcd for $\mathrm{C}_{12} \mathrm{H}_{28} \mathrm{ClNO}_{6} \mathrm{P}_{2}: \mathrm{C}, 37.95 ; \mathrm{H}, 7.43 ; \mathrm{N}, 3.69$. Found: $\mathrm{C}, 38.12$; H, 7.64; N, 3.37 .

\section{REFERENCES}

[1] G. Sturtz and H. Couthon, C. R. Acad. Sc. Paris, 316 (Serie II), 181-186 (1993). 
[2] A. Ebrahimpour, F. H. Ebetino, G. Sethuraman, and G. H. Nancollas, Determination of solubility and calcium ion stability constants of a phosphonoalkylphosphinate (PAP) and bisphosphonates (BPs) such as EHDP, Risedronate, Alendronate, 3-pic AMBP, and 3-pic AMPMP, Z. Amjad Ed., Plenum Press: New York, 295-305 (1995).

[3] W. Plöger, M. Schmidt-Dunker, and C. Gloxhuber, US PATENT, 3,988,443, (1976).

[4] D. Nelson and H. Smitherman, US PATENT, WO 92/00721 (1992).

[5] M. Nakamura, T. Ando, M. Abe, K. Kumagai, and Y. Endo, Br. J. Pharmacol., 119, 205-212 (1996).

[6] J. G. Slatter, K. L. Feenstra, M. J. Hauer, D. A. Kloosterman, A. H. Parton, P. E. Sanders, G. Scott, and W. Speed, Drug Metab. Dispos., 24 (1), 65-73 (1996).

[7] J. P. Räsänen, E. Pohjala, H. Nikander, and T. A. Pakkanen, J. Phys. Chem., 100 (20), 8230-8239 (1996).

[8] C. Dufau and G. Sturtz, Phosphorus, Sulfur Silicon Relat. Elem., 69, 93-102 (1992).

[9] J. H. Lin, Bone, 18 (2), 75-85 (1996).

[10] F. Hosain, R. P. Spencer, H. M. Couthon, and G. L. Sturtz, J. Nucl. Med., 37, 105-107 (1996).

[11] D. V. Griffiths, J. M. Hughes, J. W. Brown, J. C. Caesar, S. P. Swetnam, S. A. Cumming, and J. D. Kelly, Tetrahedron, 53 (52), 17815-17822 (1997).

[12] R. K. Harris, P. Jackson, L. H. Merwin, B. J. Say, and G. Hägele, J. Chem. Soc., Faraday Trans. 1, 84 (11), 3649-3672 (1988).

[13] R. T. Chlebowski and A. McTiernan, J. Clin. Oncol., 17 (1), 130-142 (1999).

[14] M. Mimura, M. Hayashida, K. Nomiyama, S. Ikegami, Y. Iida, M. Tamura, Y. Hiyama, and Y. Ohishi, Chem. Pharm. Bull., 41 (11), 1971-1986 (1993).

[15] T. Yokomatsu, Y. Yoshida, N. Nakabayashi, and S. Shibuya, J. Org. Chem., 59 (24), 7562-7564 (1994). 
[16] F. Cheng, X. Yang, C. Fan, and H. Zhu, Tetrahedron, 57, 7331-7335 (2001).

[17] R. A. Nugent, M. Murphy, S. T. Schlachter, C. J. Dunn, R. J. Smith, N. D. Staite, L. A. Galinet, S. K. Shields, D. G. Aspar, K. A. Richard, and N. A. Rohloff, J. Med. Chem., 36 (1), 134-139 (1993).

[18] J. C. Brelière, X. Edmonds-Alt, and G. Garcia, EP 100 718, Chem. Abstr. 1984, 100, 192078j (1983).

[19] H.-J. Cristau, C. Brahic, and J.-L. Pirat, Tetrahedron, 57, 9149-9156 (2001).

[20] D. Kantoci, J. K. Denike, and W. J. Wechter, Synth. Commun., 26 (10), 2037-2043 (1996).

[21] K. Fisher, F. Woolard, M. Leadbetter, and J. Gerdes, US PATENT, WO 96/31124, (1996).

[22] T. H. Cromartie, K. J. Fisher, and J. N. Grossman, Pestic. Biochem. Physiol., 63, 114126 (1999).

[23] D. Q. Qian, X. D. Shi, R. Z. Cao, and L. Z. Liu, Heteroat. Chem., 10 (4), 271-276 (1999).

[24] J. Ohanessian, D. Avenel, D. El Manouni, and M. Benramdane, Phosphorus, Sulfur Silicon Relat. Elem., 129, 99-110 (1997).

[25] L. Lemée, M. Gulea, M. Saquet, S. Masson, and N. Collignon, Heteroat. Chem., 10 (4), 281-289 (1999).

[26] D. C. Stepinski, D. W. Nelson, P. R. Zalupski, and A. W. Herlinger, Tetrahedron, 57, 8637-8645 (2001).

[27] A. Rockenbauer, A. Mercier, F. Le Moigne, G. Olive, and P. Tordo, J. Phys. Chem. A, 101 (43), 7965-7970 (1997).

[28] G. Olive, F. Le Moigne, A. Mercier, A. Rockenbauer, and P. Tordo, J. Org. Chem., 63 (24), 9095-9099 (1998). 
[29] F. Palacios, M. J. Gil, E. Martínez de Marigorta, and M. Rodríguez, Tetrahedron, 56 (34), 6319-6330 (2000).

[30] G. Sturtz, H. Couthon, O. Fabulet, M. Mian, and S. Rosini, Eur. J. Med. Chem., 28, 899-903 (1993).

[31] N. Kreutzkamp and G. Cordes, Ann., 623, 103-108 (1959).

[32] L. Maier, Phosphorus and Sulfur, 11, 311-322 (1981).

[33] A. Köckritz, G. Röhr, and M. Schnell, Phosphorus, Sulfur Silicon Relat. Elem., 63, 95101 (1991).

[34] D. Q. Qian, X. D. Shi, R. Z. Cao, and L. Z. Liu, Tet. Lett., 38 (35), 6245-6246 (1997).

[35] G. Olive, F. Le Moigne, A. Mercier, and P. Tordo, Synth. Commun., 30 (4), 629-627 (2000).

[36] G. R. F. M. Olive, Ph. D. Thesis, Université d'Aix-Marseille III (1998).

[37] E. W. Petillo and R. Spitzmiller, Tetrahedron Lett., 51, 4929-4930 (1979).

[38] H. Gross, B. Costisella, and L. Brennecke, Phosphorus, 4, 241-246 (1974).

[39] G. Olive and M. H. P. van Genderen, Magn. Res. Chem., 38 (5), 379-381 (2000).

[40] G. M. Blackburn, D. Brown, S. J. Martin, and M. J. Parratt, J. Chem. Soc., Perkin Trans. 1, 181-186 (1987).

[41] E. E. Nifant'ev, L. M. Runova, T. G. Shestakova, E. V. Bogatyreva, and V. I. Ronkov, Zh. Obshch. Khim., 50 (2), 304-309 (1980).

[42] U. Jahn, J. Andersch, and W. Schroth, Synthesis, (5), 573-588 (1997).

[43] J. J. Vepsäläinen, J. Kivikoski, M. Ahlgén, H. E. Nupponen, and E. K. Pohjalad, Tetrahedron, 51 (24), 6805-6818 (1995).

[44] H. Gross and B. Costisella, J. Prakt. Chem., 328 (2), 231-236 (1986).

[45] S. Pietri, M. Miollan, S. Martel, F. Le Moigne, B. Blaive, and M. Culcasi, J. Biol. Chem., 275 (26), 19505-19512 (2000). 
SCHEME 1: Yokomatsu and Qian procedures for bisphosphonates synthesis.

SCHEME 2: Our easy one pot procedure of bisphosphonates synthesis.

SCHEME 3: Hydrolysis of bisphosphonate by $\mathrm{HCl}$.

SCHEME 4: Asymmetric bisphosphonate.

SCHEME 5: Synthesized non symmetric bisphosphonates .

SCHEME 6:Aminolysis of bisphosphonate.

SCHEME 7: Modification on the phosphorus atoms.

SCHEME 8: Modification on the nitrogen atom.

SCHEME 9: Hoffmann elimination. 


$$
2 \mathrm{P}(\mathrm{OEt})_{3}+\mathrm{R}^{1} \mathrm{CONR}^{2} \mathrm{R}^{3} / \mathrm{POCl}_{3} \longrightarrow \mathrm{POCl}_{3} / \mathrm{CH}_{2} \mathrm{Cl}_{2}
$$

\section{SCHEME 1}

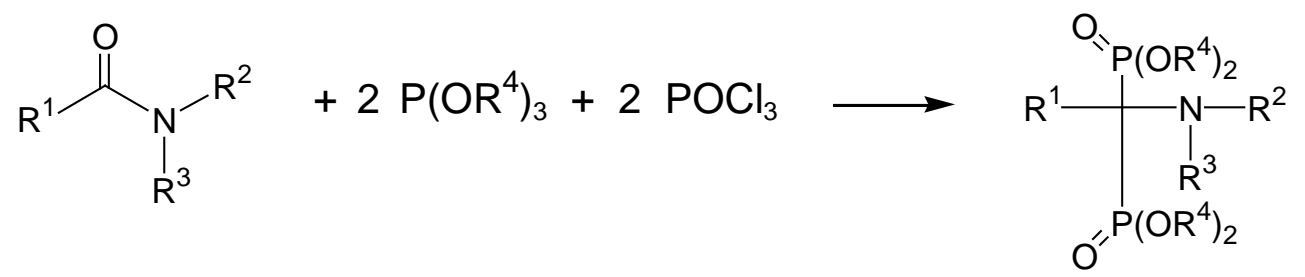

SCHEME 2

$(\mathrm{EtO})_{2}(\mathrm{O}) \mathrm{R}_{\mathrm{R}^{\prime}}^{\mathrm{P}} \chi_{\mathrm{R}^{\prime \prime}}^{\mathrm{P}(\mathrm{O})(\mathrm{OEt})_{2}}$

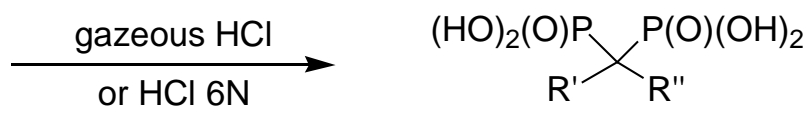

SCHEME 3<smiles>[R]C([R])(P=O)P(=O)([OH2+])OCC</smiles>

SCHEME 4 


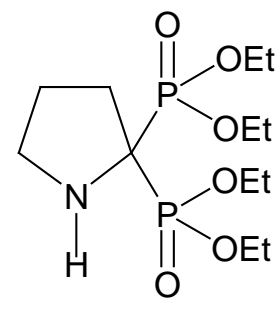

2

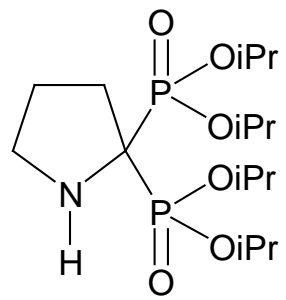

15

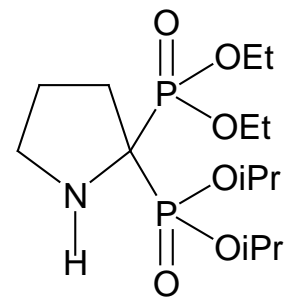

16

SCHEME 5
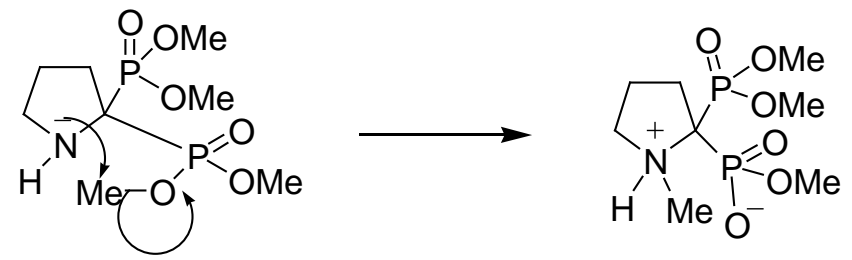

SCHEME 6

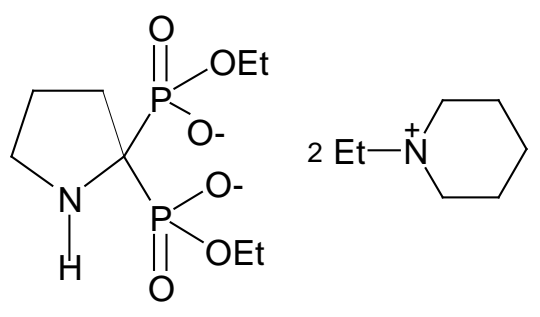

23

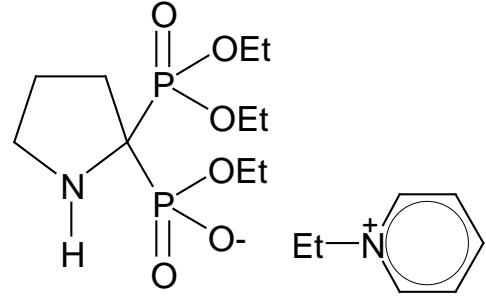

24

SCHEME 7 


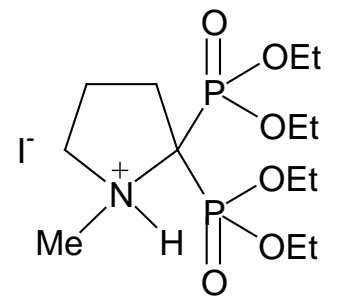

25

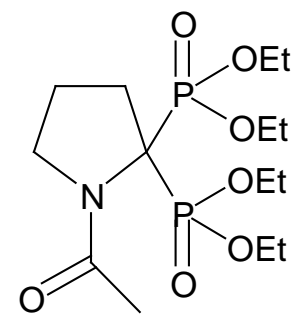

26

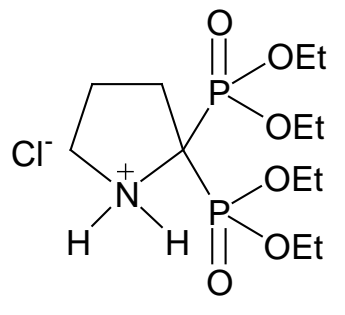

27

\section{SCHEME 8}

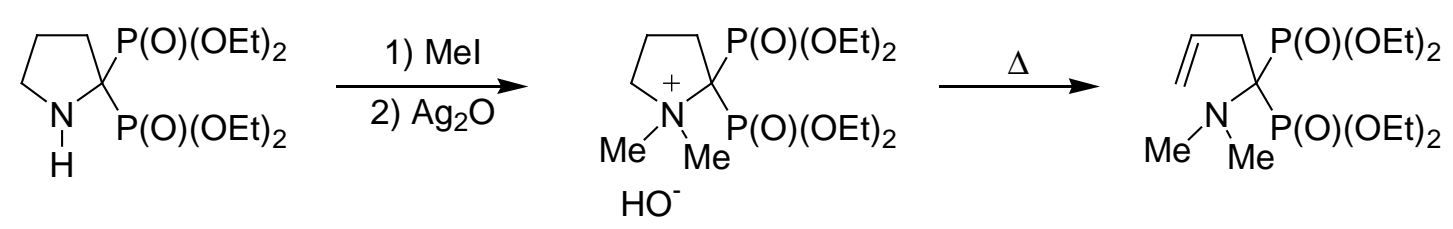

\section{SCHEME 9}

